\title{
THE GANADIAN DILEMMA: FRENCH AND ENGLISH
}

\author{
J. R. MALLORY
}

WHEN Lord Durham sought to explain the causes of the 1837 Rebellion in British North America he found the problem simple to ascribe in the province of Lower Canada. He found, he said, two nations at war within the bosom of a single state. Throughout Canadian history one of the recurring themes has been the changing patterns of co-existence of the two peoples inescapably locked in a somewhat loveless embrace on the banks of the St. Lawrence. Events of the last decade have again brought the matter of FrenchEnglish relations to the fore and, apparently, gravely imperilled the continuance of the union.

\section{The Historical Background}

Before considering present difficulties, it is worthwhile to glance at the past. In 1760 the power of France in the northern half of North America came to an end as a result of the successful British combined assault on the fortress of Quebec in the previous autumn. In 1763 France formally transferred to British control the territories which had been known as New France, abandoning in the process some sixty thousand French subjects in the colony. It was these sixty thousand French Canadians and their descendants who were to survive as a culturally and linguistically distinct enclave for over two centuries in North America. Most of them still live in the Province of Quebec, their ancient homeland lying between the Ottawa river and the Gulf of St. Lawrence. In this area they constitute nearly 80 per cent. of the population, and their majority position has ensured effective control over the provincial government, and a large enough representation in the Canadian Parliament at Ottawa to constitute an effective veto group most of the time and on most issues.

In the beginning the British authorities granted important concessions which have until now ensured their survival. In the Quebec Act of 1774 three basic concessions, already recognised, were

* The author is Professor of Political Science at MoGill University, has written Social Credit and the Federal Power in Canada and is currently completing a major study of Canadian Government. 


\section{J. R. MALLORY}

confirmed and enlarged. They were: the use of the French language in the courts and in government, the continuance of the existing French civil law (governing among other things property and personal relations such as marriage and inheritance); and the exercise of the Catholic religion (including the right, while a Catholic, to hold public office).

The foundations of modern Canadian political society were laid in the aftermath of the American Revolution. Along the St. Lawrence, beginning a hundred miles up the great river from Montreal and extending to the river's mouth, was a colony whose inhabitants were almost entirely French-speaking and Catholic. While the Quebec Act had given them the dispensation from exclusion from public office which would otherwise have been the consequence of the Protestant and Hanoverian establishment, it denied them the degree of self-government which would have come from representative institutions. They were a simple feudal people, it was thought, and such things as parliaments and elections were beyond their understanding. But this argument, whether true or not, could not be used against the flood of new settlers, refugees of the United States, who settled the newly opened lands to the west. And so, in 1791, parliamentary institutions were granted. At the same time the colony was divided into Lower Canada, which comprised the area previously settled by the French, and Upper Canada, whose settlers were of English tongue and, to a large extent, of American origin. Thus was commenced the political separation of the two peoples in British North America.

It cannot be said that representative government worked in the Canadian provinces much better than it had in the old American colonies. In both of them popular majorities tended to dominate the legislative assembly, but were excluded from both responsibility and power because they could never control the executive government. In the process, reformist politicians learned a great deal about using the power of the purse in an unending battle with the governor and his council. When the colonial executives, exasperated by the obstruction and opposition of the reformers, were able, by skilful use of bribery and intimidation, to achieve government majorities, the reformers were driven to despair. By the middle of the 1830 s both colonies were on the road to rebellion. When the rebellions broke out they were in considerable part agrarian revolts against wealth and privilege-the banks, the land companies, the merchants who seemed to prosper while the settlers struggled to 


\section{THE CANADIAN DILEMMA: FRENCH AND ENGLISH}

avoid starvation. But in Lower Canada the revolt had overtones of a struggle between the races.

The immediate reaction of the British authorities to the 1837 Rebellion was to implement Durham's recommendation that the two Canadian provinces should be united under a single government in the hope that political fusion would hasten the break-up of the rural and "feudal " character of French-Canadian society, and in the process convert the French Canadians to a more materialist and prosperous society in which the language and institutions of the old French society would wither away. This did not happen, for the strength and resilience of French-Canadian society had been greatly under-estimated.

Already by 1840 there had developed in both provinces loose party divisions of conservatives and liberals which retained their separate identities in the new Parliament. While "responsible" or Cabinet government was not conceded until 1848, it was party coalitions in the legislature which made government of the colony possible. The Anglophone parties of the West and the Francophone parties of the East retained their identity and operated a sort of informal federal system in which neither side interfered with matters of importance to the other. This solution was made all the more inevitable by the fact that the two former provinces were given equal representation in the elected lower house. Thus a separate political system for French Canada survived the union of the two provinces, which was perpetuated by the larger federation which was created in 1867.

If one looks back over the history of North America since the American Revolution, one can see that one of its most noticeable characteristics has been an uninhibited flow of people over political boundaries in response to economic stimuli. In this movement questions of political allegiance seem not to have exerted a very strong pull because of the similarities between Canada and the United States. From generation to generation people have moved back and forth across the border, intermarried and sought new homes without much regard to changes in citizenship. This movement has affected people of French stock almost as much as those of other origins. In the case of migrants of French stock, there has been one important difference. Migration to the United States, and even to other parts of Canada, has led to a rapid attrition of the French language and to assimilation into a dominant Englishlanguage culture. From this cultural annihilation there has seldom been any return. For those who opt for the Anglophone culture, 


\section{J. R. MALLORY}

freedom of movement remains-but within that cultural matrix. For the Francophone who has crossed over into the English-speaking world there can seldom be any return in later generations to the culture of the original mother tongue.

\section{The Traditional Society}

In the nineteenth century the clergy was the predominant elite in French Canada, and therefore the architects of the strategy of national survival. Strongly affected as they were by ultramontane influences in the Church, they had a pathological distrust of urbanisation and a sure conviction that the materialism of North American Anglophone civilisation would in the end draw their pcople away from the faith, as well as from their national identity. Accordingly, they preferred to preserve French-Canadian society in Quebec as a largely rural and static one, insulated as far as possible from contaminating contact with the bustling industrialisation of the cities, and animated by a marked distrust of the state as an instrument of national development.

By a strategy of withdrawal into the fortress-province of Quebec it was possible to put up a dogged resistance to the aggressive expansion of the English-speaking majority. The costs of this strategy were high, both in terms of the economic welfare of the FrenchCanadian habitant, and in the necessity to write off as lost those who had emigrated either to the United States or to the rest of Canada. In the last analysis, the only sure foundation of the faith was the preservation of the nation in its bucolic purity.

French-Canadian society in this form was to a degree a truncated one, lacking a commercial and industrial bourgeoisie. In consequence, there was created in Quebec a class, as well as a racial, division between the predominantly English and Scottish economic ruling class, and a French-Canadian proletariat and peasantry, led and inspired by the traditional professional classes: clergy, lawyers and doctors. These occupied the key roles of middlemen, whether in dealing with an employer in the village, or as politicians delivering the votes to support the interests of the business class. Since the clergy controlled the educational system, they directed its energies to preparing young men for the priesthood or the other ancient professions. For the many, public authority provided a system of elementary education. Beyond that education in college and university was in the private sector, and intended for the few. A career in business, or even engineering and science, was not a life style to 
which the young in the classical colleges were taught to aspire. This attempt to isolate the bourgeoisie from the world of business was effective until well into the twentieth century. This was painfully obvious during the Second World War, when few, if any, French Canadians could be found to exercise positions of influence in the vast wartime bureaucracy which had been recruited chiefly from the world of business. The difficulty was illustrated by a letter from the Minister of Munitions and Supply on May 8, 1941 :

"I think I have made my attitude clear in relation to this position. I have always been anxious to appoint a French Canadian, realising how important it is that our Purchasing Agent at Quebec should speak French. However, I have been equally insistent that this officer should be experienced in the business of purchasing. ... I am still prepared, and anxious, to appoint a French Canadian if the person with the right qualifications can be found." 1

What was the attitude of English-speaking Canadians to the "French fact" during most of the first century after Confederation? It must be said that even the most liberal of them regarded French Canada as little more than a transitory source of trouble and discomfort which, in the long run would somehow be solved by the ultimate penetration of the forces of "progress" into Quebec. Meanwhile it was best to let sleeping dogs lie.

It seems now to be accepted that one of the basic sources of political division in Western countries is religion, rather than class or ideology. This was certainly true in Canada. It has been impossible at times to prevent the political temperature rising to dangerous heights, as in the aftermath of the rebellions in Manitoba and the North West in 1870 and 1885 when anti-Catholic and antiFrench feeling ran high in Ontario. Prudent politicians realised that no political party could succeeed without heavy bloc-support from French and Catholic Quebec, but that this must be combined with policies of non-interference in the satrapy of the FrenchCanadian leaders and of a damping-down of issues which might divide French from English.

And so the two groups co-existed in the mutual incomprehension of their two solitudes. On the English-speaking side a dcepseated Protestant suspicion of the Roman Catholic Church persisted. This was coupled with a feeling that the French language was an anomaly in an English-speaking continent, and that FrenchCanadians were both backward and reactionary and thus tended to

I Royal Commission on Bilingualism and Biculturalism, Report, Book IIIa (1969), p. 106. The Commission argues, no doubt correctly, that the exclusion of French Canadians was not so much from the absence of talent, as from their exclusion from the informal network from which recruitment took place. 


\section{T. R. MALLORY}

weaken the forces of progress in Canada. One found also a touch of the North American radical belief that a good state could be built in the New World only by destroying the cultural roots of "foreigners" who must be assimilated in order to build a new Canada. ${ }^{2}$ Political realities kept these feelings fairly well below the surface most of the time, but in provinces where French Canadians were in a minority (New Brunswick, Ontario, Manitoba and the new prairie provinces) effective steps were taken to eradicate the use of French as a language of instruction in "separate" (i.e., Catholic) schools. Only in Quebec itself was the French language safe, and even there the existence of a largely Anglophone business class made English the exclusive language of communication in most of the world of work.

Against this persistent pressure, the French-Canadian reaction was to husband their political strength, to limit as far as possible the impact of twentieth-century industrialisation on the habitant whose backwardness and ignorance-so it was thought-would be a solid barrier against the secular and integrating forces of urban and industrial society. It suited the purposes of Premier Maurice Duplessis to maintain this situation, though he found that the encouragement of the exploitation of Quebec's natural resources by big business was a useful source of both tax revenue and party funds. At the same time he adopted a policy of insulation in defence of " provincial rights" by refusing to co-operate in federallysponsored schemes of highway construction, extended welfare and assistance to higher education. In the last-named case at least his hostility was a matter not only of principle but of politics, for the universities of French Canada were not only the centres of intellectual opposition to his regime but were also beginning to breed a new generation of social scientists, many of whom became the leaders of a growing trade union movement against which he blatantly used the provincial police on the side of employers. When Duplessis died in 1959 his policy of immobilism died with him.

\section{The New Nationalism}

For even resource-based industries (mining, pulp and paper, etc.) create an urban proletariat and Quebec could not be isolated from the enormous social effects of wartime and post-war Canadian industrialisation. A new elite pattern, which had been emerging

2 See Ramsay Cook, The Politics of John W. Dafoe and the Free Press (Toronto, 1963), pp. 292-293. 


\section{THE CANADIAN DILEMMA: FRENCH AND ENGLISH}

in French Canada, suddenly became visible. Traditional leadership had been the exclusive preserve of the ancient professions, but now their leadership was challenged by a new social configuration in which the engineers and managers of industrial society have become more important than the traditional classes. For them, the old Catholic and agrarian nationalism of the past has been rejected, and replaced by a new and fiercer sense of identity.

Where the old nationalism was defensive, the new nationalism aims at creating something new. "Its aim", says Professor Charles Taylor, "is not to defend the traditional way of life, but to build a modern French society on this continent. In its pure form, practically the only value it has in common with the old is the French language itself." 3 It thus has the quality, not only of a rejection of the dominant Anglo-Saxon values of North America, but of a revulsion against nearly all of the traditional values of French Canada. The carriers of this new nationalism are what Professor Taylor calls the new intelligentsia, who include intellectuals, journalists, teachers, economists and others of the new breed of civil servants who began to play a major role in Quebec after 1960.

Spurred onward by the nationalists in a hurry into communications industries, and by civil servants exhilarated by the feeling that they are making a revolution of modernisation, political leaders have been borne along on a tide of rising expectations from government. For it is, above all, to the power of the state that the leaders of the new Quebec look for the satisfaction of the new wants and the generation of the economic development which will enlarge the opportunities for all. For them, these things must be done by their own French-Canadian state of Quebec, and not by Ottawa. For this there are two reasons: the new elites wish to share in the management of the new society, and Quebec has much ground to make up to catch up with the rest of Canada. For this reason, incidentally, their social priorities are likely to be different from those articulated in Ottawa. Given the scarcity of both financial resources and human resources available at any one time, their priorities for collectivised welfare for the ill, the aged and the disadvantaged are low as compared with the need to put resources into education and economic growth.

For a significant number of the most articulate of the new elite,

3 "Nationalism and the Political Intelligentsia: A Case Study", Queen's Quarterly, Vol. LXXII, No. 1 (Spring, 1965). 


\section{J. R. MALLORY}

the logic of the situation drives them inevitably to a separatist position--that the independence of Quebec from the rest of Canada is the only acceptable solution. For this there are many reasons, some of them external. In a world where the new states of what is called the Third World are born in profusion, in response to much the same revolt against "colonialism" and traditional values, it must secm exasperating that the French-Canadian nation is denied the trappings of separate existence in a world which welcomes Gabon and Jamaica. And many of the most articulate of them are expressing their plight in the rhetoric of colonial exploitation, which aims at a compound of socialism and nationalism visible in most of the newly emerging states. It is possible to evoke a considerable response to agitation conceived on these lines, for the grievances and fears which are being exploited are real enough and clamour for relief.

The prime cause for the fears for the survival of French Canada is demographic. Until the middle of the present century there were many prominent French-Canadian nationalists who consoled themselves with the reflection that the relatively high birthrate of French Canadians in Quebec would not only ensure their survival as a minority of decisive size in Canada, but might well bring about a "revanche des berceaux" which, by making them a majority at the end of the day, would reverse the verdict of the Conquest. A quick reading of the census returns in 1951 destroyed that comforting illusion. The urbanising and secular forces of the twentieth century had entered what Prime Minister Trudeau called, in another connection, the bedrooms of the nation. The birthrate in French Canadian families has fallen, and is continuing to drop in relation to the rest of the country. Furthermore, whereas natural increase among Anglophones is heavily reinforced by immigration, the accretion of immigrants to the Francophone community is negligible. The causes of this are various. Immigration from France is very small and, given the disinclination of the metropolitan Frenchman to move, unlikely to increase. Other immigrants from southern Europe who, as Catholics, might be thought to be easy to attract into the Francophone community prefer instead to send their children to English-language schools. So marked is this trend that French Canadians face the possibility, by the end of the present century, of being a minority in Montreal and, with the tendency of large metropolitan areas to agglomerate, possibly in the province itself in the long run.

This prospect lies at the root of much of the present troubles 


\section{THE CANADIAN DILEMMA: FRENCH AND ENGLISH}

in Montreal over the attempts of some school boards to phase out English-language schooling, to proposals that immigrants should be compelled to send their children to French-language schools, and to widespread demands for unilingualism as the only effective defensive measure against the rising tide of English.

\section{The Language Question}

The threat to the survival of French Canadians as a distinct group is not only demographic, it is the result of almost unbearable tensions in the world of work. The extent of these problems is only now adequately explored in the most recent Report of the Royal Commission on Bilingualism and Biculturalism. They reveal, all too clearly, that for the middle class, prosperity contains the everpresent threat of what it is now fashionable to call cultural genocide. As Canada passes into the post-industrial phase the same fate awaits the urban worker.

For English is the language of the work world in the shop and in the office. The French Canadian, even in his own province, must often leave his language at home when he goes to work. Communication with superiors in business must be in English, for they are mainly monoglot, and the larger the business the more it deals with-and is probably owned by-the international world of big business. Only on the factory floor are the language roles reversed, and even there instructions and manuals were often in English only. Even within the trade union, the higher officials would be Anglophones from Toronto, or in the case of "international " unions, from the United States. The Royal Commission found that, though these were matters of common knowledge they had not even been the objects of reliable research, and it was necessary to get the facts by special research studies. They found that

"socially and economically, Francophones are in a far weaker position than Anglophones in the work world. They are decidedly and consistently lower in average income levels, in schooling levels, in occupational scales, and in the ownership of industry. Reflecting these findings were those showing the meagre participation of Francophones in the upper levels of the Federal Public Service and private industry and the restricted use of the French language in these institutions." 4

Anyone who has ever been compelled to work with others in a language not his own must realise the extent to which it diminishes

4 Royal Commission on Bilingualism and Biculturalism, Report, Book IIIa, p. 5. 


\section{J. R. MALLORY}

effective participation. It not only prevents one from doing one's best, by a process of attrition it lowers self-esteem and induces a downward spiral of achievement.

It must be said that the willingness and capacity of the public service to accommodate itself to the needs of bilingualism was negligible before the $1960 \mathrm{~s}$. Difference in mother tongue, education, habits of thought and culture, effectively denied equality of access of French-speaking Canadians to the public service. The removal of patronage and the effective introduction of the merit system in the first two decades of the present century had the result of excluding all but those French Canadians who were, by reason of education and background, thoroughly bilingual and, in essence, Anglicised.

"Until recently", says the B. \& B. Commission, "the inconsistency between the ideal of equal access and the fact of Anglophone dominance of the federal Public Service was rarely questioned within the federal administration. ... When they could not ignore arguments [for increased Francophone participation ] ... federal leaders-Francophone and Anglophone alike -usually countered them by suggesting the superiority of English technology and training, the lack of French interest in the federal sphere, and the absolute necessity of preventing representational and patronage claims (which were usually equated) from encroaching upon the merit system. Now the situation is changing: Quebec's recent evolution has produced, on the one hand, Francophones who are more conscious of their power as a cultural group to challenge the dominance of the other culture in the Public Service, and, on the other, some Anglophones who are sensitive to Francophone dissatisfaction with federal institutions. There is also an awareness, at least within some sections of both the Public Service and the wider Canadian community, that the pattern of Anglophone dominance hinders the development of adequate staff resources and generally militates against effective federal administration." $s$

Since 1964 the federal authorities have shown a growing awareness of developing an adequate response, prodded since 1965 by periodic reports from the Commission. One of the most sweeping measure was the Official Languages Act of 1969 which declared the two languages to be of equal status in all aspects of the federal government and administration, and enjoined all federal departments, agencies and crown corporations to ensure that they were able to serve the public in either of the two official mother tongues. For the public service, the vast majority of whose members are still effectively unilingual Anglophones, the process of adaptation will take time-even if assisted by voluntary language courses and 


\section{THE CANADIAN DILEMMA: FRENCH AND ENGLISH}

bonuses for useful bilingual skills. The present $\mathrm{cmphasis,} \mathrm{as} \mathrm{recom-}$ mended by the Commission, is on the development of "receptive bilingualism ", that is, capacity in the public service to read and understand communications, formal and informal, addressed to them, so that communications can be freely initiated in either language. (To give an example of the old practice: a long speech setting out the Canadian position at the UN on a particular issue was drafted in English, sent to New York and then translated for delivery in French. At that time the Minister was a Francophone, the Under-Secretary of State, who was permanent head of the Department was Francophone, as were a number of the officers who probably drafted the speech, and the Canadian Delegate who delivered the speech was a Francophone.) The underlying theme is "equal partnership", which implies the absence of linguistic handicaps in recruitment, examination, promotion and everyday work. As a means of strengthening this, the Commission has recommended that there should in fact be French language units in all major departments in which the working language is French.

These measures, as applied to the Public Service, reflect a response to very strong pressures indeed to reach a new accommodation between the two communities. They reflect a growing acceptance by the major political parties that a bilingual and bicultural regime is the price of the survival of the federal system. Among Anglophone Canadians there is considerable support for the view that this is not only a necessary political compromise, but a GOOD THING. One should not create the impression that this liberal and rather establishment view is universally held. There is some backlash, and the possibility that it will spread. In the first place among the ranks of the Public Service itself there is a " bulldog party" which regards the spread of bilingual and bicultural changes in the Public Service as a threat to their security, their expectations and to the sacred merit system itself. Also, the further one moves west the more often one hears the bewildered and exasperated cry of "What does Quebec want?" These regions are not only largely free of French-Canadian minorities of any significance of their own. They are also the regions which were so heavily settled by European immigrants a generation or two ago. Among them, it seems, the need to socialise linguistic minorities into an English-speaking "Canadian" culture has been most strongly felt. The question arises in their minds why German, or Ukrainian-which are spoken still by large minorities in parts of the prairies-have no status and French-spoken by few-does. The 


\section{J. R. MALLORY}

answer, a mixture of history and contemporary politics, does not convince them. How far this group can be dragged into accepting major compromises, not only over the French language, but also over the structure of the federal system, is not an easy question to answer.

\section{Partnership or Separatism?}

Paradoxically, at the point when for the first time in history the federal government, and the country generally, is in a mood to accept the idea of a country in which there is a genuine and effective partnership of the two races, the French-Canadian people in Quebec have rudely turned their backs on it and are turning more and more to embrace some kind or other of separatism. The prevailing temper in the government of Quebec, ramifying downward even to local school boards, has changed from the long-standing position of live and let live to one of aggressive integration into the French culture. Historically, both political and social practice in Quebec had been for the two communities there (Anglophones are rather more than 20 per cent. of the population and-now-largely in the Greater Montreal area) to exist side by side, each controlling its own and not interfering with the other. There was a dual education system, nominally Protestant and Catholic, but chiefly divided on racial lines. There was, even-so it is said-a "no proselytising" agreement between Catholic and Protestant worked out tacitly. This, incidentally, explains the repressive fury of the Duplessis regime against Jehovah's Witnesses. While only a Catholic would regard them as Protestant, they were bitterly resented for having broken the understanding not to seek converts from the Catholic community.

The reason for the change in predominant sentiment in Quebec springs from a change in the power relationships in Quebec society. On the one hand, there has been a sharp decline in the power and prestige of the Church, both as a veto group and as the intellectual centre of French-Canadian nationalism. There is also the changed outlook and altered composition of the middle class. Lastly, there is the growing importance of a trade union movement whose objectives transcend bread-and-butter issues and are coloured by wider issues. The principal obstacle to rapid change is the dominant position still held in the electoral system by the rural areas, whose resentment at the discomforts of innovation led to the unexpected defeat of the Liberal Party-architects of the "Quiet Revolution" -in 1966. 
In the past it was the middle-class professional whose career lay in business or the bureaucracy who found-as the B. \& B. Commission has demonstrated - that his language and education were a handicap in a competitive world so that he was driven either to accept meekly cultural integration into the Anglophone world of business, and the inferior status which was the consequence of his educational and linguistic handicap, or was driven out of the province to meet the same fate in the lower reaches of the federal bureaucracy. Now the middle class is more self-conscious and self-confident so that with the backing of government and public opinion both the public and private sectors are driven to accept the necessity of French as a language of work even at levels near the commanding heights. The enormous expansion of state activity in Quebec led to a massive efflux into the Quebec bureaucracy from Ottawa and from the private sector. As a consequence, careers that do not involve linguistic and cultural attrition are now open on a much larger scale in the province.

The consequence of this is twofold. On the one hand, the elite classes are more and more convinced that the province is "their government", while Ottawa seems more and more remote and alien. As the provincial government's competence and selfconfidence grows, its needs and ambition more and more exceed the confines of the constitution. Since the province has jurisdiction over education and, so it is claimed, cultural matters generally, it becomes more and more difficult to accept the federal government as the only "international" presence which can negotiate internationally on these matters. At a time when metropolitan France and its satellites have found the extension of "Francophonie" to be a useful and cheap means of playing power politics there is no lack of encouragement from Quebec's onetime motherland. Until recently, it could be said that estrangement between France and New France was mutual: today the rediscovery of a long-lost family relationship has been a source of mutual delight. French indifference to Quebec has endured unchanged from the French Revolution until de Gaulle. The hostility of the French-Canadian hierarchy to "godless", "secular" and "liberal " France was undying. But the hierarchy is no longer the power centre of French Canada and, of course, even the hierarchy has become one of the more modern wings of the Church. The visit of General de Gaulle in 1967 triumphantly sealed the family reunion. And French and Quebec Ministers and officials share a mischievous joy in embarrassing the Government of Canada on all possible occasions. 


\section{J. R. MALLORY}

There is another reason why influential Quebec intellectuals and politicians have chosen to elevate the Province into the French Canadian state. It is clear that, given the nature of the Quebec economy which is rich in extractive resources, there is no hope of "repatriating" the commanding heights of the business community so that they will be owned and run by French Canadians. But while ownership is impossible, control is not. Since much of Quebec is poor, underdeveloped and perhaps incapable of prosperous growth there must be both a massive input of resources into development and an equally massive redistribution of wealth to achieve adequate welfare in the region. Therefore it is argued that the important thing is to control the "levers of power" through the nationalised hydro-electric power industry and of investment funds as incentives to growth industry. There is implied in this policy a much more dirigiste economy than is likely to be achieved anywhere else in North America.

Perhaps the most ominous sign of all is the composition of those groups outside political parties who are the principal pressure groups for extreme nationalist or separatist objectives. One of the most effective of these as a propaganda organisation was the evocatively named Estates General, a vast assembly which claimed to be made up of democratically selected representatives from regions and private groups (chambers of commerce, trade unions, etc.) from all over the province. Its assemblies also included representatives from Francophone groups from other parts of Canada although tension between them and the Quebecois was endemic, since a separatist position by the assembly was of little comfort to such groups as the Acadians of New Brunswick. In the periodical meetings of the Estates General the most numerous and persistent activists have been school teachers and students from universities and colleges. These same groups were the mainstay of the massive demonstrations put together in the winter of 1969-70 in support of a policy of French unilingualism in the schools. It led the leaders of both political parties to remonstrate at the impropriety of putting together great demonstrations of school children-many of whom were quite young-led by their teachers, on a complex public issue.

I doubt if enough is known about how decisive the influence of the school is in socialising the child and inculcating political values. But in Quebec, where an overwhelming majority of school teachers appear to have embraced near-separatist nationalism, it may well be that the next generation of adults will have been wholly converted 


\section{THE CANADIAN DILEMMA: FRENCH AND ENGLISH}

to the idea of an independent Quebec, so that any political debate on the subject will have been foreclosed.

\section{Continued Uncertainty}

Meanwhile, what evidence there is is ambiguous. The recent election for the provincial parliament, held on April 29, may have led to a temporary stabilisation of the situation. The shattering defeat of the Union Nationale government was partly the consequence of its own deep internal divisions between its traditional internal base and the near-separatism of some members of the Cabinet. The resulting severe internal quarrels exacerbated the government's inability to cope effectively with serious economic difficulties. The election, which might have given it a new lease of life, turned out to be badly mistimed.

What seems to have been the fatal blow was the decision of the reactionary and populist Creditistes (the self-willed and autonomous wing of Social Credit) to enter provincial politics in Quebec after a decade in which they had shown remarkable resilience in federal politics. There were many rural seats in which much of the electoral support and even some of the local organisation of the Creditistes and the Union Nationale were held in common. An open conflict between the two for the first time sealed the fate of many a Union Nationale candidate, and often that of his Creditiste rival. The consequence was greatly to inflate the success of the Liberals, who can now be expected, with over seventy seats in a legislature of 108, to take a more federalist line than their predecessors, though one which is likely to be strongly autonomist.

They have the more reason for this because of the comparative success of the Parti Quebecois, the only genuine separatist party. This party, endowed with a charismatic and attractive leader in Rene Levesque, a former television broadcaster and Liberal Cabinet Minister, and a policy of separation from Confederation followed by negotiation with English Canada for an economic community embracing the succession states, succeeded in polling 24 per cent. of the total vote and seven seats. Levesque's strategy was undoubtedly to aim at a balance of power which would force another election and put his party in the position of a real contender for power next time around. This strategy might well have succeeded had not the fortuitous intervention of the Creditistes broken a possible stalemate between the Liberals and the Union Nationale. As things are Levesque failed to win a seat for himself, and it may be more 


\section{J. R. MALLORY}

difficult for him to follow a cool strategy, while his more disappointed followers turn to extra-political and less peaceful methods.

It is probable that the bulk of the support of the Parti Quebecois is among the young. The voting age in Quebec is eighteen, and the apparently high poll in the 1970 election suggests that voters under twenty-five must have voted in unprecedented numbers. Even assuming that separatism is being supported most strongly by those at the youthful end of the age spectrum, it does not necessarily follow that in each year a number of traditional voters will disappear from the electoral rolls and be replaced by a permanent bloc of separatist voters. Many of those who, as students, may have been unqualified separatists may modify their views as they grow older. As their adult world becomes closely bound up with jobs, children and mortgage payments, they may slip into a "silent majority " which is quite prepared to accept the world as they find it, and totally unwilling to live dangerously and pay a serious economic price for the politics of national self-determination.

Nevertheless it will, in all probability, be a world in which the survival of French-Canadian cultural identity becomes more feasible as a result of the growing sensitivity of Canadian businesses and government institutions to the problem of cultural identity. And cultural identity may suffice. A recent study of the attitudes of young French-Canadian elites by Professor Erwin Hargrove suggests that among his group of young professionals "political nationalism, as such, is not very intense," but there is an almost overwhelming urge " for fulfilment, for complete development as French-speaking persons in a French-speaking society of its own distinctive culture"."

Perhaps the most serious danger to the survival of the Canadian union is a change in the basic cleavages in the political system. In the past religion seems to have been more important than class or ethnicity. When it threatened at times to emerge as a basic cleavage, the party system was always successful in transcending it. If religion declines in significance, and is replaced by ethnicity, the threat to the legitimacy of the political system is much more real. For one thing religion as a cleavage did cut across ethnic lines, for there are a large number of Anglophone Catholics. For another, religion is not a serious challenge to the legitimacy of a regime.

- Erwin C. Hargrove, "Nationality, Valucs, and Change: Young Elites in French Canada", Comparative Politics (April, 1970), p. 498. 


\section{THE CANADIAN DILEMMA: FRENCH AND ENGLISH}

Organised religions are committed by both history and doctrine, to accepting the legitimacy of the political regime in which they find themselves. Ethnic nationalism, unlike religion, is far more likely to challenge the legitimacy of the political system. It is thus more revolutionary in its effects.

The forces of "Canadian" nationalism which hold together a weak federal system like Canada are fairly tenuous. Against them the forces of French-Canadian nationalism are strong-as they are bound to be in any community which is self-consciously engaged in a struggle for survival. And at the moment the balance between the forces of unity and the forces of diversity is affected, perhaps decisively, by a French-Canadian Prime Minister of Canada who is tough and resolute, but fallible and mortal. 